\title{
Estuarine nitrogen retention independently estimated by the denitrification rate and mass balance methods: a study of Norsminde Fjord, Denmark
}

\author{
Kurt Nielsen ${ }^{1}$, Lars Peter Nielsen ${ }^{2}$, Per Rasmussen ${ }^{3}$ \\ ${ }^{1}$ Marine Department, Environmental Division, Aarhus County Council, Lyseng Allé 1, DK-8270 Højbjerg, Denmark \\ ${ }^{2}$ Department of Microbial Ecology, Institute of Biological Science, University of Aarhus, DK-8000 Aarhus, Denmark \\ ${ }^{3}$ Water Consult, Stendyssevej 22, DK-4171 Glumsø, Denmark
}

\begin{abstract}
Nitrogen retention was studied in a small, shallow estuary (Norsminde Fjord, Denmark) by 2 independent methods: (1) measurement of denitrification rate using the isotope pairing technique; and (2) estimation of mass balances established on the basis of hydrodynamic numerical modelling. Denitrification rates were found to range from 100 to $1600 \mu \mathrm{mol} \mathrm{N} \mathrm{m} \mathrm{N}^{-2} \mathrm{~d}^{-1}$, and varied considerably from February to May. The seasonal and spatial variation in denitrification rate was positively related to the water column $\mathrm{NO}_{3}{ }^{-}$concentration. The average annual denitrification rate was $29 \mathrm{~kg} \mathrm{~N} \mathrm{ha}^{-1} \mathrm{yr}^{-1}$, or approximately $6 \mathrm{t} \mathrm{N} \mathrm{yr}^{-1}$ for the entire estuary. This compared well with the annual nitrogen retention of approximately $8 \mathrm{t} \mathrm{N} \mathrm{yr}^{-1}$ calculated from the mass balances. Annual denitrification and nitrogen retention in the estuary accounted for approximately $2 \%$ and $3 \%$, respectively, of total nitrogen input from the catchment area. These low values are explicable by the high water exchange rate in the estuary, freshwater retention time being 1.5 to $13 \mathrm{~d}$, with minimum values during the winter. The present study therefore lends no support to the widely held assumption that estuarine denitrification generally amounts to 40 to $50 \%$ of the nitrogen input. The findings indicate that in addition to nitrogen input from the land, consideration must also be given to the water residence when estuarine nitrogen retention is being estimated.
\end{abstract}

KEY WORDS: Estuary Eutrophic $\cdot$ Denitrification $\cdot$ Isotope pairing $\cdot$ Loading $\cdot$ Mass balance $\cdot$ Model Nitrogen $\cdot$ Retention

\section{INTRODUCTION}

Estuaries are often characterized by high productivity caused by high nutrient input from terrestrial runoff and sewage effluent. Of primary importance in this respect is nitrogen, although phosphorus may also play a role - typically during the spring (Ryther \& Dunstan 1971, Boynton et al. 1982, Sand-Jensen \& Borum 1991, Sand-Jensen et al. 1994). Part of the nutrient input in eutrophic areas is temporarily retained as high primary producer biomass, i.e. phytoplankton and benthic micro- and macrophytes (Monbet 1992, Sfriso et al. 1992, Valilea et al. 1992, Cahoon et al. 1993). Estuarine nitrogen retention $\left(\mathrm{N}_{\text {ret }}\right)$ also takes place through immobilization in the sediment or as a result of denitrification.
Most estimates of estuarine $\mathrm{N}_{\text {ret }}$ are based on estimates of sediment $\mathrm{N}_{2}$ fluxes and terrestrial input of inorganic nitrogen. On the basis of an analysis of data from the Baltic Sea and 6 estuaries in different parts of the world, Seitzinger $(1988,1990)$ concluded that 40 to $50 \%$ of estuarine nitrogen load is retained by denitrification, the figure being independent of the biological and hydrographic structure of the estuary or the technique used to measure denitrification. Whether or not this ' $50 \%$ rule' is generally applicable is uncertain; moreover, no clear explanation has yet been offered to account for it. The question is important since the ' $50 \%$ rule' is sometimes applied when estimating nitrogen transport from land to the sea during the compilation of total nitrogen budgets for open marine waters, e.g. Kattegat/Skagerrak (Ertebjerg et al. 1991, North Sea Task Force 1993). 
Another approach to studying estuarine $N_{\text {ret }}$ is to determine the ecosystem mass balance. However, this approach has only rarely been applied to marine ecosystems (Wulff et al. 1990, Kamp-Nielsen 1992, Larsen et al. 1992), probably due to difficulties in estimating nutrient exchange with the open sea. To our knowledge, no parallel determination of estuarine $\mathrm{N}_{\text {ret }}$ using both methods has previously been reported.

The purpose of the present study was to determine annual $N_{\text {ret }}$ in a small, eutrophic estuary using both the denitrification rate (isotope pairing technique) and mass balance (hydrodynamic numerical modelling) methods. The study was undertaken in Norsminde Fjord, Denmark, and was part of the aquatic monitoring programme jointly conducted by the Aarhus County Council and the National Marine Research Programme, HAV 90.

\section{MATERIALS AND METHODS}

Study area. The study was undertaken from February 1992 to February 1993 in Norsminde Fjord, a shallow estuary situated on the east coast of Jutland, Denmark (Fig. 1, Table 1). The surface area is $1.86 \mathrm{~km}^{2}$

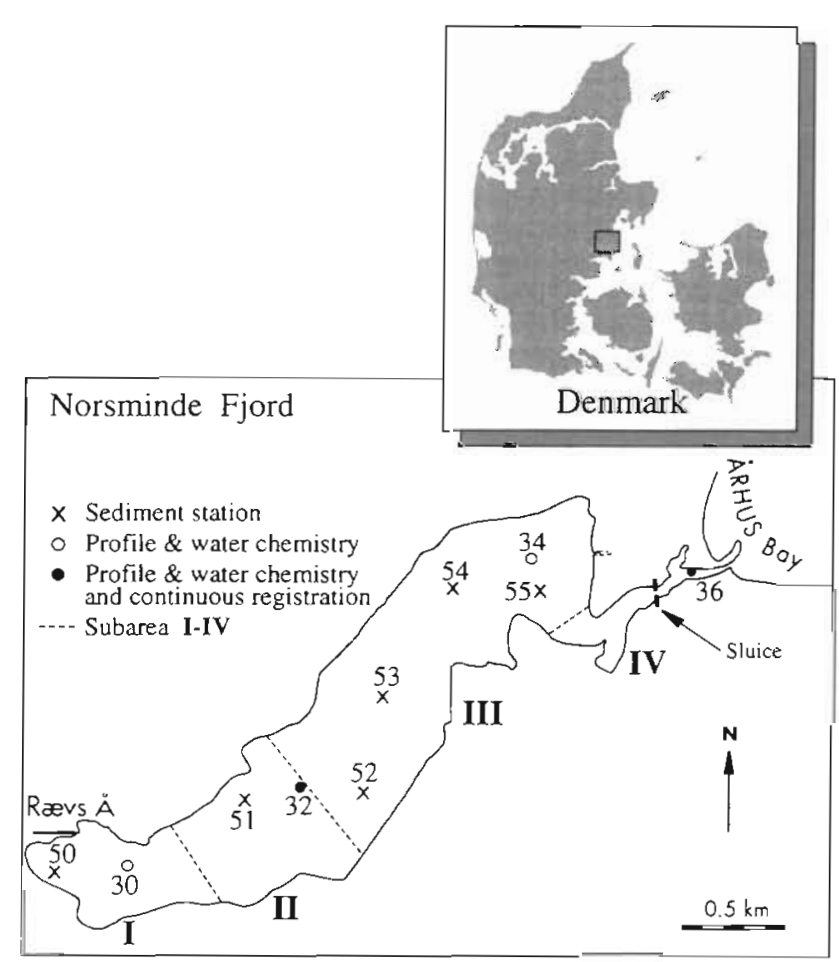

Fig. 1. Norsminde Fjord, Denmark, showing the main freshwater inlet, Rævs $\AA$, the sluiced outlet to Aarhus Bay and the sampling stations for water chemistry, sediment and continuous registration of temperature and salinity. The 4 subareas used in the numerical hydrodynamic model are also indicated
Table 1. Characteristics of Norsminde Fjord

Catchment area
Length
Surface area
Mean depth
Maximum depth
Volume
Tide

$101 \mathrm{~km}^{2}$

$5 \mathrm{~km}$

$1.86 \mathrm{~km}^{2}$

$0.6 \mathrm{~m}$

$2.0 \mathrm{~m}$

$1.1 \times 10^{6} \mathrm{~m}^{3}$

$0.2 \mathrm{~m}$

and the mean depth only $0.6 \mathrm{~m}$. The catchment area comprises $101 \mathrm{~km}^{2}$ of intensively farmed agricultural land. The main freshwater input is Rzevs $\AA$, a small stream that drains $85 \%$ of the catchment area and enters the estuary at its innermost part. The outflow to Aarhus Bay is a narrow channel protected by a sluice which closes at sea water level $+0.35 \mathrm{~m}$ (to prevent excessive influx of sea water!

The sediment ranges from soft mud with an organic matter content of about 10 to $15 \%$ (ignition loss) to fine/medium-sized sand with a low organic matter content ( $1 \%$ ignition loss). The organic matter content is generally highest in the relatively deeper, central part of the estuary (Aarhus County Council 1994.)

Loading and hydrography. The main freshwater input to the estuary was calculated on a daily basis from the water level using a calibrated water level/ water flow relationship for Rævs $\AA$. Additional input from the remainder of the catchment area was estimated on the basis of the input from the Rævs $\AA$ catchment area using the measured nitrogen input per $\mathrm{km}^{2}$ from the latter. Chemical analysis of the stream water was performed 18 times during the study period. Nitrogen input was calculated from the product of daily water flow and nitrogen concentration using the $C / Q$ method; knowing the daily water flow, the daily values of nitrogen concentration can be estimated from the empirical model of nitrogen concentration $(C)$ and water flow (Q) (Walling \& Webb 1981).

Salinity and temperature profiles were measured with a CTD probe every 2 to $3 \mathrm{wk}$ at 4 permanent monitoring stations (Fig. 1). Surface water was analysed for total-nitrogen (dissolved and particulate), nitrate and ammonium every 2 to 3 wk at 3 stations. During stratification, bottom water was also analyzed. The water samples were stored at the in situ temperature until required, analysis being performed by conventional methods within 3 h (Greenberg 1992). Water level, salinity and temperature were recorded digitally every 15 min during most of the study period at 2 of the stations, 1 in the centre of the estuary and 1 at its mouth (Fig. 1).

The estuary was ice covered in January 1992, and temperature was at its maximum (20 to $25^{\circ} \mathrm{C}$ ) during May to July. Salinity varied considerably, ranging 
from $0.1-19.4 \%$ in the inner part of the estuary to $3.7-27.3 \%$ in the outer part. Despite the shallow depth, the water column was stratified approximately $15 \%$ of the year (Aarhus County Council 1994)

Denitrification rate. The sediment at 6 stations distributed along the length of the estuary (Fig. 1) was sampled on 9 occasions at 2 to $7 \mathrm{wk}$ intervals from February to December 1992. During each sampling, 2 sediment cores were collected in plexiglass tubes (10 $\mathrm{cm}^{2}, 3 \mathrm{~cm}$ sediment, $7 \mathrm{~cm}$ water column) mounted on a rod. The sediment cores were kept at the in situ temperature and subjected to both light and dark incubation within 1 to $5 \mathrm{~h}$. Denitrification was measured using the isotope pairing technique whereby the denitrification rate is calculated from the accumulation of single- and double-labelled $\mathrm{N}_{2}$ following addition of ${ }^{15} \mathrm{NO}_{3}{ }^{-}$to the water column (Nielsen 1992). A magnetic stirrer was placed in each core $(60 \mathrm{rpm})$ and ${ }^{15} \mathrm{NO}_{3}{ }^{-}$ from a $10 \mathrm{mM}$ stock solution $\left(99 \%{ }^{15} \mathrm{NO}_{3}{ }^{-}\right)$was added to the water column of each core to a final concentration of 50 to $100 \mu \mathrm{M}^{15} \mathrm{NO}_{3}^{-}$. This concentration has previously been found to be optimal for measurements in similar estuarine sediments (Pelegri et al. 1994). The cores were stoppered and incubated for 0.5 to $3 \mathrm{~h}$ depending on the season. At the end of the incubation the whole core was mixed with a rod and a sample of the slurry taken for mass spectrometric analysis of accumulated ${ }^{15} \mathrm{~N}_{2}\left({ }^{14} \mathrm{~N}^{15} \mathrm{~N}\right.$ and $\left.{ }^{15} \mathrm{~N}^{15} \mathrm{~N}\right)$, as described by Nielsen (1992). The in situ denitrification of unlabelled $\mathrm{NO}_{3}^{-}\left(D_{14}\right)$ was calculated from the accumulation of the $2^{15} \mathrm{~N}_{2}$ species (Nielsen 1992):

$$
D_{14}=\frac{{ }^{14} \mathrm{~N}^{15} \mathrm{~N}}{2\left({ }^{15} \mathrm{~N}^{15} \mathrm{~N}\right)} \times\left[\left({ }^{14} \mathrm{~N}^{15} \mathrm{~N}\right)+2\left({ }^{15} \mathrm{~N}^{15} \mathrm{~N}\right)\right]
$$

The exact isotopic composition of $\mathrm{NO}_{3}{ }^{-}$in the water column during incubation was not measured, and the sources of $\mathrm{NO}_{3}^{-}$for denitrification (diffusion from the overlying water or nitrification within the sediment) could not, therefore, be distinguished, except during periods when the water column lacked $\mathrm{NO}_{3}{ }^{-}$.

Numerical modelling. Model description: Numerical, hydrodynamic modelling of Norsminde Fjord was undertaken using a 2-dimensional, hydrodynamic model - the MIKE 21 model system - comprised of a hydrodynamic (HD) submodel and an advectiondispersion (AD) submodel (Abbott et al. 1981, Warren \& Bach 1992, Danish Hydraulic Institute 1993). The HD submodel simulates the water level and the current velocity at each time step and in each grid point. It solves the depth-integrated hydrodynamic equations, i.e. the continuity equation and conservation of momentum in 2 horizontal dimensions (Ekebjærg \& Justesen 1991). The momentum equation includes the effects of the wind shear stress on the water surface, as well as the effects of the Coriolis force and bed friction, the latter being described by a term including the Chezy number.

The MIKE 21 AD model simulates simultaneously with the HD calculations the transport and concentration of dissolved or suspended matter by solving the 2-dimensional advection-dispersion equation:

$$
\frac{\partial c}{\partial t}+u \frac{\partial C}{\partial x}+v \frac{\partial C}{\partial y}=D_{x} \frac{\partial^{2} C}{\partial x^{2}}+D_{y} \frac{\partial^{2} C}{\partial y^{2}}-F C
$$

where $c$ is concentration; $t$ is time, $\Delta t$ being the time step in the simulation; $x$ and $y$ are 2 horizontal directions (the $x$ direction may be selected as any horizontal direction, and it will often be one of the main flow directions in the model area under consideration; the $y$ direction is perpendicular to the $x$ direction); $u$ is the current velocity in the $x$ direction; $v$ is the current velocity in the $y$ direction; $D_{x}$ is the dispersion coefficient in the $x$ direction; $D_{y}$ is the dispersion coefficient in the $y$ direction; $F$ is the coefficient of linear decay, $F \geq 0$ (the term $F C$ can be considered as a sink term).

In the $\mathrm{AD}$ submodel, the dispersion coefficient is a measure of all longitudinal water exchange not taking place by advection with the depth-integrated mean flow in the calculation grid. Variations in bed topography, turbulence generated by bed or wind friction and the presence of longitudinal density (salinity) gradients may all influence the magnitude of the dispersion coefficient, which may therefore be subject to considerable temporal and spatial variation.

Model set-up: The MIKE 21 model of Norsminde Fjord was set up in a horizontal grid with the grid size fixed at $100 \mathrm{~m}$ in each direction. In the model, freshwater from the catchment area is set to discharge into the estuary at 3 locations, the major part being the innermost lateral inflow which drains $92 \%$ of the catchment area (i.e. Raevs $\AA$ and a few minor streams). Precipitation was included in the model as an additional freshwater source. All freshwater sources were based on daily average values (Water Consult 1993). The boundary condition at the coastal limit of Norsminde Fjord was the water level variation at Norsminde Sluice. This was digitized as $15 \mathrm{~min}$ values such that tidal movement of the water was included in the model.

In shallow waters like Norsminde Fjord, the wind action on the water surface may be of especially great significance for estuarine water flow. Such effects were included in the simulations as wind time series with 3-hourly values of wind speed and direction.

Model calibration: The hydrodynamic model of the estuary was calibrated on the basis of all the discharge, water level and salinity data. The main calibration parameter in the HD submodel was the size of the Chezy number (the bed resistance factor), while that in the $\mathrm{AD}$ submodel was the dispersion coefficient. 
During calibration of the AD submodel it was found that the simulated salinity levels were extremely dependent on the dispersion coefficients employed, particularly in the inner part of the estuary. The study period of 1 full year was divided into 18 shorter periods ranging in duration from 5 to $30 \mathrm{~d}$ and averaged $20 \mathrm{~d}$ (Table 2). In addition, the estuary was divided into 4 subareas (Fig. 1) in which dispersion coefficients were specified separately, period by period.

Estimation of freshwater residence time: Freshwater residence time was mainly estimated from a few simulations with the calibrated MIKE 21 AD model involving the initial 'discharge' of a pulse of tracer into Rævs $\AA$. The propagation of this pulse through the estuary to Aarhus Bay was followed by calculating mass transport at each time step through pre-selected cross sections, as well as total accumulated transport of mass through each section. Using this method the residence time of treshwater was calculated for 2 selected periods. The residence time for other periods was estimated on the basis of the residence times determined for the 2 selected periods, together with a knowledge of the varidion in freshwater discharge and the estimated dispersion coefficients.

Mass balance determination: Nitrogen concentrations were simulated with the calibrated MIKE $21 \mathrm{AD}$ model for all 18 time periods. The dominant nitrogen source was freshwater discharge from the catchment area, input in the form of precipitation being negligible. The simulations were carried out by discharging the freshwater with a varying concentration of nitro-

Table 2. Calculated coefficients of dispersion $\left(\mathrm{m}^{2} \mathrm{~s}^{-1}\right)$ in the 4 subareas of Norsminde Fjord during the period February 1992 to February 1993

\begin{tabular}{|c|c|c|c|c|c|}
\hline \multirow[t]{2}{*}{ Period } & \multirow[t]{2}{*}{ Date } & \multicolumn{4}{|c|}{ Coefficient of dispersion } \\
\hline & & I & II & III & IV \\
\hline 1 & 11 Feb 1992-11 Mar 1992 & 60 & 60 & 60 & 60 \\
\hline 2 & 11 Mar 1992-18 Mar 1992 & 60 & 60 & 60 & 60 \\
\hline 3 & 18 Mar 1992-23 Mar 1992 & 30 & 30 & 30 & 30 \\
\hline $3 b$ & 23 Mar 1992-01 Apr 1992 & 5 & 20 & 30 & 30 \\
\hline 4 & 01 Apr 1992-16 Apr 1992 & 30 & 30 & 30 & 30 \\
\hline $4 b$ & 16 Apr $1992-23$ Apr 1992 & 2 & 5 & 10 & 20 \\
\hline 5 & 23 Apr 1992-16 Mai 1992 & 20 & 20 & 20 & 20 \\
\hline $5 b$ & 16 May 1992-26 Mai 1992 & 2 & 3 & 5 & 20 \\
\hline 6 & 26 May 1992-15 Jun 1992 & 2 & 3 & 10 & 20 \\
\hline 7 & 15 Jun 1992-06 Jul 1992 & 20 & 20 & 20 & 20 \\
\hline 8 & 06 Jul 1992-05 Aug 1992 & 3 & 5 & 10 & 20 \\
\hline 9 & 05 Aug 1992-24 Aug 1992 & 3 & 5 & 10 & 20 \\
\hline 10 & 24 Aug 1992-23 Sep 1992 & 2 & 3 & 10 & 20 \\
\hline 11 & 23 Sep $1992-15$ Oct 1992 & 3 & 3 & 3 & 3 \\
\hline 12 & 15 Oct $1992-12$ Nov 1992 & 10 & 10 & 10 & 20 \\
\hline 13 & 12 Nov 1992-09 Dec 1992 & 2 & 20 & 40 & 60 \\
\hline 14 & O9 Dec 1992-07 Jan 1993 & 2 & 20 & 40 & 60 \\
\hline 15 & 07 Jan 1993-08 Feb 1993 & 10 & 20 & 20 & 40 \\
\hline
\end{tabular}

gen specified for each source. At the coastal boundary, the concentration time series was fixed on the basis of measurements in Aarhus Bay at intervals of 1 to 4 wk (Aarhus County Council unpubl. obs.).

Denitrification or immobilization in the sediment was included in these simulations by adjusting the decay coefficient $(F)$ relating to the concentration of dissolved nitrogen. For each simulation period the decay coefficient was initially set to zero. If necessary, i.e. if simulated nitrogen concentrations were too high, the decay coefficient was adjusted until the simulated values fitted the nitrogen concentrations measured in the estuary. Release of nitrogen from the sediment to the water could be modelled by adding a source term.

The simulation providing the best fit was then used to calculate the mass balances. The latter provide information on nitrogen transport in and out of the estuary for each period, as well as storage, denitrification/sediment retention and sediment release.

\section{RESULTS}

\section{Denitrification}

Denitrification rates ranged from $100 \mu \mathrm{mol} \mathrm{N} \mathrm{m}{ }^{-2}$ $\mathrm{d}^{-1}$ in July to $1600 \mu \mathrm{mol} \mathrm{N} \mathrm{m}{ }^{-2} \mathrm{~d}^{-1}$ in April (Fig. 2). Considerable temporal variation was seen, especially during the period February to May, the denitrification rate thus decreasing from 1500 to $400 \mu \mathrm{mol} \mathrm{N}$ $\mathrm{m}^{-2} \mathrm{~d}^{-1}$ from February to March, then increasing again to $1600 \mu \mathrm{mol} \mathrm{N} \mathrm{m}{ }^{-2} \mathrm{~d}^{-1}$ from March to April. From May to July there was a gradual decline and the denitrification rate was almost constant (100 to

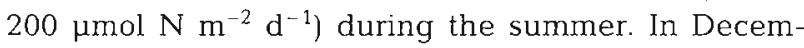
ber, the denitrification rate increased to $600 \mu \mathrm{mol} N$ $\mathrm{m}^{-2} \mathrm{~d}^{-1}$.

There was a significant correlation between seasonal variation in denitrification rate and $\mathrm{NO}_{3}{ }^{-}$concentration $\left(r^{2}=0.96\right)$ (Fig. 3). That the denitrification rate exceeded $200 \mu \mathrm{mol} \mathrm{N} \mathrm{m}{ }^{-2} \mathrm{~d}^{-1}$ when $\mathrm{NO}_{3}{ }^{-}$was present in the water, but was only 100 to $200 \mu \mathrm{mol} \mathrm{N} \mathrm{m} \mathrm{N}^{-2} \mathrm{~d}^{-1}$ when $\mathrm{NO}_{3}^{-}$was absent (Fig. 3), indicates that the major source of $\mathrm{NO}_{3}{ }^{-}$for denitrification was $\mathrm{NO}_{3}{ }^{-}$in the water column rather than $\mathrm{NO}_{3}{ }^{-}$produced in the sediment by nitrification. The low $\mathrm{NO}_{3}{ }^{-}$concentrations during the summer period were attributable to the lower $\mathrm{NO}_{3}{ }^{-}$input via freshwater, as well as to the uptake of $\mathrm{NO}_{3}^{-}$by macro- and microalgae. Annual mean denitrification rate decreased gradually from the inner to the outer part of the estuary, the rate being 3-fold greater at Stn $50\left(810 \mu \mathrm{mol} \mathrm{N} \mathrm{m}{ }^{-2} \mathrm{~d}^{-1}\right)$ than at Stn $55\left(270 \mu \mathrm{mol} \mathrm{N} \mathrm{m}{ }^{-2} \mathrm{~d}^{-1}\right)$ (Fig. 4). This is mainly due to the parallel decline in $\mathrm{NO}_{3}{ }^{-}$concentration in the 
Fig. 2. Average denitrification rate and nitrate concentration in Norsminde Fjord during 1992 (average of 6 stations)

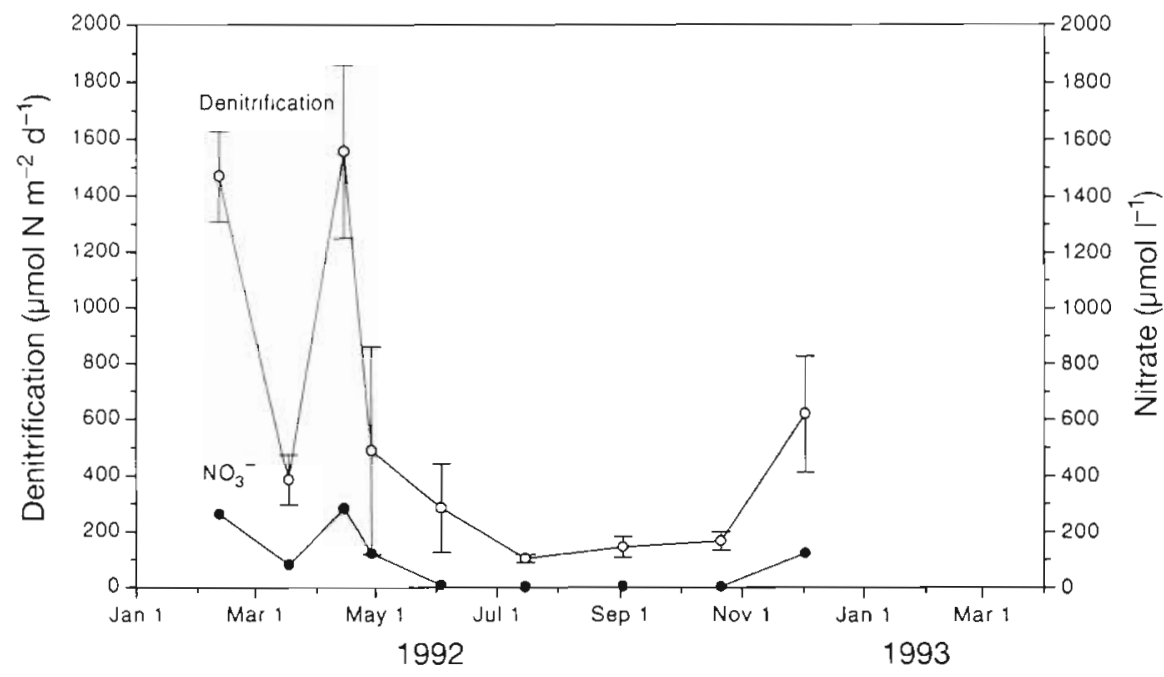

Nitrogen mass balances

water due to gradual dilution of the inflowing $\mathrm{NO}_{3}$ containing freshwater by saline water from Aarhus Bay.

Total annual $N_{\text {ret }}$ in Norsminde Fjord due to denitrification was estimated to be $29 \mathrm{~kg} \mathrm{ha}^{-1} \mathrm{yr}^{-1}$, or $5.4 \mathrm{t} \mathrm{yr}^{-1}$ for the entire estuary. $\mathrm{N}_{\text {ret } \%}$ determined from denitrification therefore amounted to approximately $2 \%$ of total freshwater nitrogen input.

\section{Dispersion coefficients and freshwater residence time}

The estimated dispersion coefficients ranged from 2 to $60 \mathrm{~m}^{2} \mathrm{~s}^{-1}$, and were generally lowest in the inner part of the estuary (subareas I and II), reflecting the low rates of water mixing in these very shallow parts (Table 2). The great variation seen in the dispersion coefficients during 1992 is attributable to the weather conditions. The coefficients were generally lowest during the summer period.

The estimated freshwater residence time in Norsminde Fjord was less than $14 \mathrm{~d}$ throughout the year. During the winter period, when the freshwater input to the estuary was greatest, residence time was extremely low (1.5 to 5 d). During the summer period, freshwater residence time was typically 3 to $13 \mathrm{~d}$. The fast water exchange reflects the relatively small volume of the estuary compared to the freshwater input $\left(0.57\right.$ to $\left.2.65 \times 10^{6} \mathrm{~m}^{3} \mathrm{yr}^{-1}\right)$ and the tidal exchange volume. In addition, winddriven circulation in the shallow waters probably enhances the mixing processes.

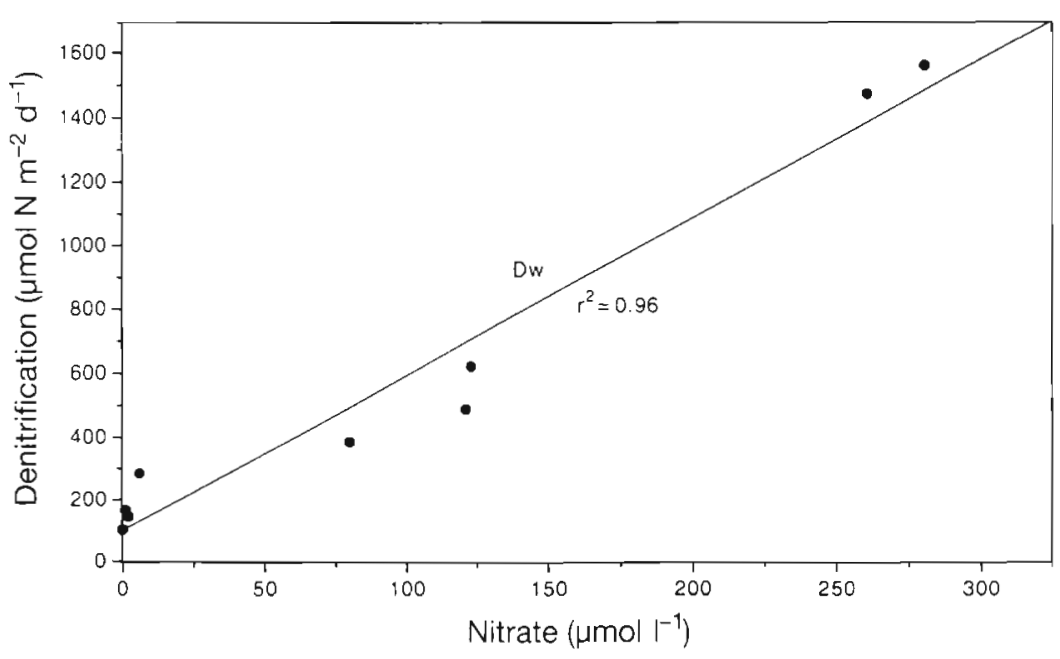

Fig. 3. Average denitrification rate in Norsminde Fjord as a function of the water column $\mathrm{NO}_{3}{ }^{-}$concentration (same data as Fig. 2)
The estimated mass balance for the 18 separate periods revealed little or no nitrogen retention during most of the year, freshwater input being balanced by transport out of the estuary to Aarhus Bay. The exceptions were April to May (periods $4 b, 5$ and $5 b$ ), where $N_{\text {ret }}$ ranged from 1800 to $6900 \mu \mathrm{mol} \mathrm{N} \mathrm{m}^{-2} \mathrm{~d}^{-1}$, and in August to October (periods 9,10 and 11), where it ranged from 1400 to $3400 \mu \mathrm{mol} \mathrm{N} \mathrm{m}{ }^{-2} \mathrm{~d}^{-1}$ (Fig. 5).

The estimated monthly nitrogen input, output and retention are shown for Norsminde Fjord in Table 3. The annual nitrogen balance is illustrated in Fig. 6. Annual freshwater input of nitrogen to the estuary was estimated to be $307 \mathrm{t} \mathrm{N} \mathrm{yr}^{-1}$ during the $1 \mathrm{yr}$ study period (1 February 1992 to 31 January 1993). Annual atmospheric deposition of nitrogen was estimated to be 


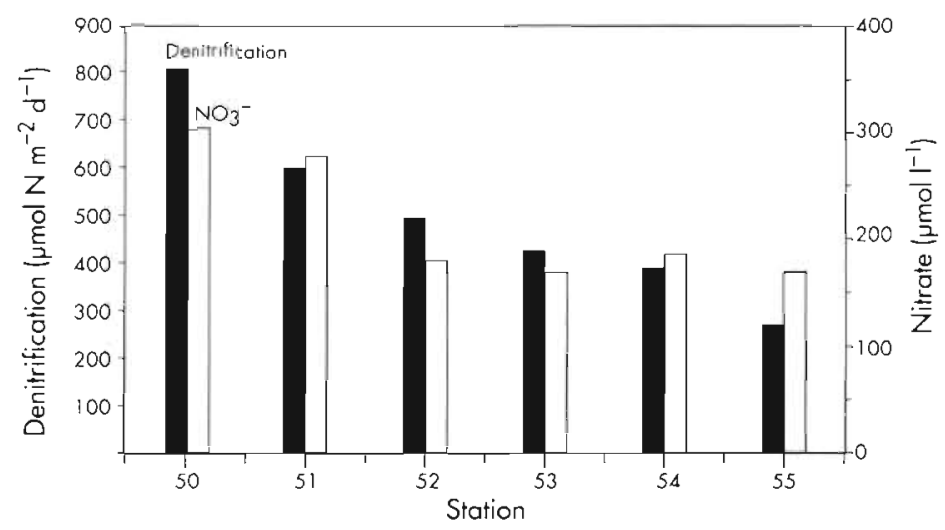

Fig. 4. Denitrification and nitrate concentration along a transect from the inlet to the outlet of Norsminde Fjord. Values are the yearly average

$2 \mathrm{t} \mathrm{N} \mathrm{yr}^{-1}$ based on the study of Hovmand et al. (1993). Net output of nitrogen to Aarhus Bay was $298 \mathrm{t} \mathrm{yr}^{-1}$, annual $\mathrm{N}_{\text {ret }}$ in the estuary thus being approximately $8 \mathrm{t}$ $\mathrm{N} \mathrm{yr}^{-1}$. $\mathrm{N}_{\text {ret\% }}$ determined from the mass balance therefore amounted to approximately $3 \%$ of the total freshwater nitrogen input. The influx of nitrogen to the estuary from Aarhus Bay was estimated to be $37 \mathrm{t} \mathrm{N}$ $\mathrm{yr}^{-1}$, or approximately $12 \%$ of net output from the estuary to the bay. The amount of nitrogen present in the estuary water column was approximately 3 t greater at the end of the 1 yr study period than at the beginning (Fig. 6). ization and denitrification. As the seasonal pattern of these processes differs, they can only be expected to balance over a full annual cycle.

That considerable benthic nitrogen mineralization takes place in Norsminde Fjord is apparent from the high ammonia and urea effluxes measured over an annual cycle (1200 to $8000 \mu \mathrm{mol} \mathrm{N} \mathrm{m}^{-2} \mathrm{~d}^{-1}$ and 100 to $1100 \mu \mathrm{mol} \mathrm{N}$ $\mathrm{m}^{-2} \mathrm{~d}^{-1}$, respectively) (M. S. Therkildsen \& B. Aa. Lomstein unpubl.). Benthic assimilation of $\mathrm{NO}_{3}{ }^{-}$in the estuary is reported to be 15000 $\mu \mathrm{mol} \mathrm{N} \mathrm{m} \mathrm{m}^{-2} \mathrm{~d}^{-1}$ (Risgaard-Petersen et al. 1994). Since the gross benthic fluxes of nitrogen therefore greatly exceed the net loss by denitrification (100 to $1600 \mu \mathrm{mol} \mathrm{N} \mathrm{m}^{-2} \mathrm{~d}^{-1}$ ), a general absence of synchrony between $N_{\text {ret }}$ and denitrification is not surprising. The closely similar values for yearly $N_{\text {ret }}$ obtained with the 2 methods suggests that burial of organic nitrogen in sediment is negligible in Norsminde Fjord, this being in contrast to the situation in some other estuaries (Yoon \& Brenner 1992).

The linear correlation found between denitrification rate and water column $\mathrm{NO}_{3}{ }^{-}$concentration (Figs. 3 \& 4) was surprising considering the expected variability of other known regulating factors, e.g. the penetration depth of oxygen in the sediment, effects of benthic microphytes and benthic fauna activity. In 2 other Danish estuaries, Kertinge Nor and Skive Fjord, it has been found that denitrification of $\mathrm{NO}_{3}^{-}$from the water column is a function of both $\mathrm{NO}_{3}{ }^{-}$concentration and penetration depth of oxygen (Rysgaard et al. 1995, T. Dalsgaard et al. pers. comm.).

Benthic microphytes are usually abundant in shallow Norsminde Fjord, and numerous studies have shown are 2 very different and truly independent approaches to estimating estuarine retention of nitrogen. Thus the similar values for $\mathrm{N}_{\text {ret }}$ obtained with these 2 methods in the present study $(6$ and $8 \mathrm{t} \mathrm{N} \mathrm{yr}^{-1}$, respectively) support the validity and reliability of both approaches in ecosystems of this type.

Except for the month of April, when there was a peak in both measured denitrification rate and $N_{\text {ret }}$ calculated from the mass balances, the seasonal variation in $\mathrm{N}_{\text {ret }}$ seen with the 2 methods did not compare well. While this is partly because the hydrodynamic model inadequately simulates short-term variation, temporal changes in the sediment nitrogen pool may also affect the estimates. Nitrogen accumulates in the sediment as a result of the deposition of particulate organic matter and the assimilation of nitrogen by benthic microand macrophytes. Loss from the sediment occurs through particle resuspension, mineral-

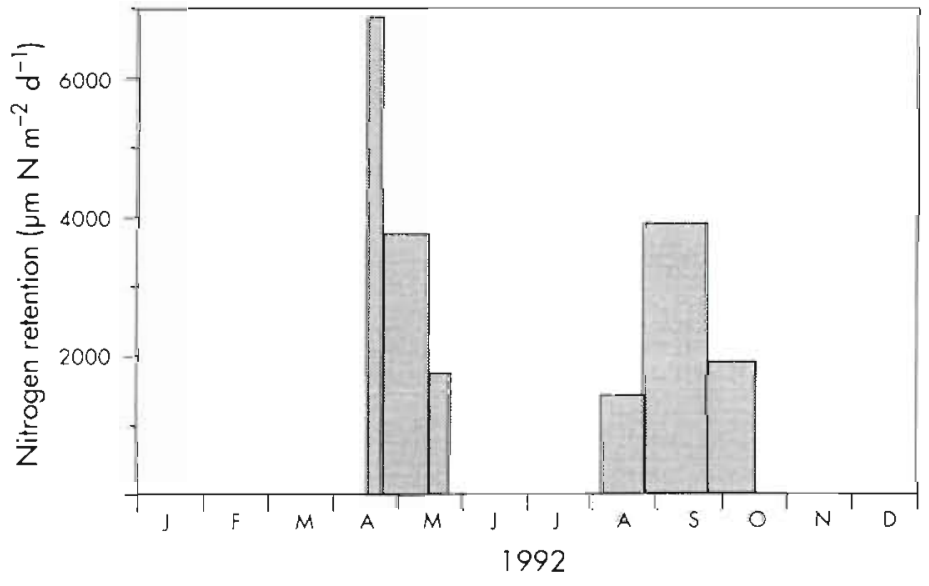

Fig. 5. Nitrogen retention in Norsminde Fjord calculated from the mass balance for each of the 18 periods in which the study period was divided (1 February 1992 to 31 January 1993). For all periods except those shown, retention was zero 
Table 3. Monthly mass balance for nitrogen in Norsminde Fjord (1992 to 1993) calculated from the 2-dimensional hydrodynamic model, MIKE 21. The imbalance in individual months is attributable to storage in the estuary

\begin{tabular}{|lcccc|}
\hline Month & $\begin{array}{c}\text { Freshwater } \\
\text { input }(\mathrm{t})\end{array}$ & $\begin{array}{c}\text { Atmospheric } \\
\text { deposition }(\mathrm{t})\end{array}$ & $\begin{array}{c}\text { Retention } \\
(\mathrm{t})\end{array}$ & $\begin{array}{c}\text { Net output } \\
\text { to Aarhus Bay (t) }\end{array}$ \\
\hline Feb & 25.3 & 0.15 & 0 & 26.0 \\
Mar & 50.2 & 0.21 & 0 & 47.2 \\
Apr & 30.0 & 0.28 & 2.1 & 32.1 \\
May & 10.8 & 0.07 & 2.0 & 9.6 \\
Jun & 2.0 & 0.01 & 0 & 2.6 \\
Jul & 2.8 & 0.25 & 0 & 2.7 \\
Aug & 4.1 & 0.30 & 1.6 & 2.1 \\
Sep & 2.3 & 0.15 & 2.0 & 1.4 \\
Oct & 2.4 & 0.19 & 0.8 & 1.6 \\
Nov & 36.8 & 0.17 & 0 & 32.7 \\
Dec & 50.3 & 0.11 & 0 & 53.4 \\
Jan & 90.3 & 0.11 & 0 & 86.3 \\
Total & 307.3 & 2.00 & 8.5 & 297.7 \\
\hline
\end{tabular}

Fjord and known to stimulate nitrification/ denitrification is the polychaete Nereis diversicolor (Kristensen et al. 1991). Very high stimulation of denitrification [140\% increase at a density of 1000 ind. $\mathrm{m}^{-2}$ (wet wt approximately $500 \mathrm{mg}$ )] has recently been observed when worms of this species actively filter the water (M. P. Olsen \& H. Blackburn pers. comm.). The mean in situ density of $N$. diversicolor in Norsminde Fjord was 460 ind. $\mathrm{m}^{-2}$, but the individuals were very small (mean dry wt $3.5 \mathrm{mg}$ ) (Aarhus County Council 1994). Knowing that their dry weight is $17 \%$ of their wet weight, and that their pumping rate is proportional to their body weight (Riisgărd 1991), it can be calculated that the presence of this species enhanced denitrification in the estuary by a maximum of $3 \%$.

that they can interfere with denitrification by assimilating inorganic nitrogen and altering both organic matter input and oxygen penetration depth (e.g. Christensen et al. 1990, Nielsen \& Sloth 1994, RisgaardPetersen et al. 1994). The most pronounced effect of benthic microphytes is the almost complete elimination of nitrification and denitrification when nitrogen availability from the water column is low (Nielsen \& Sloth 1994, Nielsen et al. 1994). This may explain why the summer denitrification rates in Norsminde Fjord were low (100 to $200 \mu \mathrm{mol} \mathrm{N} \mathrm{m}^{-2} \mathrm{~d}^{-1}$ ) compared to those measured in the absence of microphytes at a depth of $15 \mathrm{~m}$ in Aarhus Bay (100 to $500 \mu \mathrm{mol} \mathrm{N}$ $\mathrm{m}^{-2} \mathrm{~d}^{-1}$ ) (Nielsen et al. 1994).

Another factor of importance is the presence of bioturbating benthic invertebrates, which may stimulate denitrification by pumping water through the sediment. When the crustaceans Corophium spp. were added to sediment from Norsminde Fjord at a density of 20000 ind. $\mathrm{m}^{-2}$, the denitrification rate increased 5-fold (Pelegri et al. 1994). At the time the present study was undertaken, Corophium spp. were abundant (up to 5000 ind. $\mathrm{m}^{-2}$ ) in the inner part of Norsminde Fjord, although mean density in the estuary was only 650 ind. $\mathrm{m}^{-2}$ (Aarhus County Council 1994). Assuming a linear relationship between Corophium spp. density and stimulation of the denitrification rate, it can be calculated that the presence of this invertebrate explained approximately $13 \%$ of the total denitrification rate. Another bioturbating species common to the sediment of Norsminde
Denitrification rates are generally around $20 \mathrm{~kg} \mathrm{~N}$ $\mathrm{ha}^{-1} \mathrm{yr}^{-1}$ in Danish coastal areas (Nielsen et al. 1994), but slightly higher in estuaries such as Norsminde Fjord (Rysgaard et al. 1995, Dalsgaard et al. pers. comm.). Thus although $N_{\text {ret\% }}$ was relatively low in Norsminde Fjord ( 2 to $3 \%$ ), the annual denitrification rate was relatively high ( $29 \mathrm{~kg} \mathrm{~N} \mathrm{ha}^{-1} \mathrm{yr}^{-1}$ ), this being due to the high water column nitrate concentration.

Denitrification in Norsminde Fjord has previously been estimated on the basis of measurements made at one of the permanent monitoring stations in the estuary (Jørgensen \& Sørensen 1988, Binnerup et al. 1992). It was concluded that the denitrification rate was as high as $500 \mu \mathrm{mol} \mathrm{N} \mathrm{m}^{-2} \mathrm{~h}^{-1}$, i.e. that $25 \%$ of the freshwater input (about $50 \mathrm{t} \mathrm{N} \mathrm{yr}^{-1}$ ) was denitrified in the estuary. However, the station was located within $50 \mathrm{~m}$

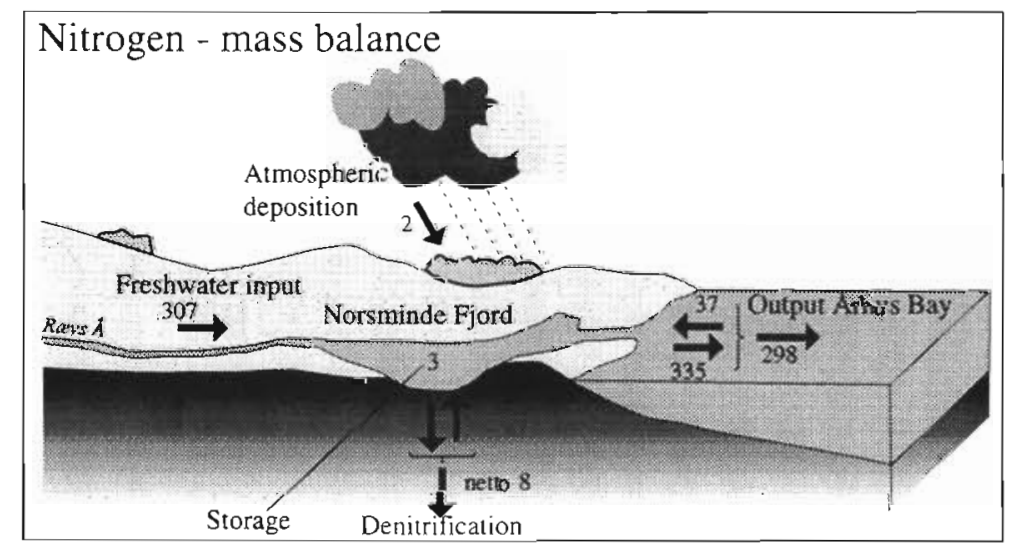

Fig. 6. Annual nitrogen balance for Norsminde Fjord over the period 1 February 1992 to 31 January 1993 showing main sources and sinks in t $\mathrm{yr}^{-1}$. Nitrogen retention and net output to Aarhus Bay were calculated on the basis of the hydrodynamic mathematical model 
of the Rævs A outlet, where the nitrate concentration is

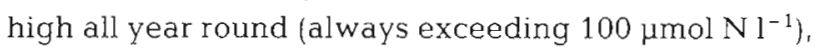
and infaunal abundance and the precipitation of fresh organic material are high. The annual denitrification rate at that location (1.4 to $2.0 \mathrm{~mol} \mathrm{~N} \mathrm{~m}^{-2} \mathrm{yr}^{-1}$ ) therefore greatly exceeds the mean rate for the estuary as a whole. The previously reported $\mathrm{N}_{\text {ret } \%}$ of $25 \%$ for Norsminde Fjord is therefore an overestimate.

In marine ecosystems, the magnitude of $\mathrm{N}_{\text {ret } \%}$ due to denitrification probably depends on the residence time. The relatively short residence time (1.5 to $13 \mathrm{~d})$ in Norsminde Fjord implies that due to simple lack of physical contact with the sediment, only a minor part of the nitrogen in the water column will be denitrified. This effect is greatest during winter periods of high freshwater input since the water column nitrogen concentration is then high and the retention time low.

The low $\mathrm{N}_{\text {ret } \%}$ found in the present study with the denitrification rate and mass balance methods ( $2 \%$ and $3 \%$, respectively) lends no support to the concept that estuarine denitrification is generally 40 to $50 \%$ (Seitzinger 1988, 1990). It is more likely the case that $\mathrm{N}_{\text {rel\% }}$ is low in estuaries and coastal areas with a short residence time, and high $(>50 \%)$ in large marine ecosystems with a long residence time, e.g. the Baltic Sea (Wulff et al. 1990).

Considerable amounts of nitrogen are transported to the Kattegat - Belt Sea area through estuaries with low residence times (Nielsen et al. 1993, Borum 1994). Thus if Seitzinger's '50\% rule' is applied when estimating nitrogen transport to open Danish seas (Extebjerg et al. 1991, North Sea Task Force 1993), nitrogen loading of this eutrophic area will probably be significantly underestimated.

Acknowledgements. We thank Peter Boller for his enthusiastic assistance during the field work, Tony E. Larsen for his support with hydrodynamic modelling, and David I. Barry for revising the manuscript.

\section{LITERATURE CITED}

Abbott, M. B., McCowan, A., Warren, I. R. (1981). Numerical modelling of free-surface flows that are two-dimensional in plan. In: Fischer, H. B. (ed.) Transport models for inland and coastal waters. Academic Press, New York, p. 222-283

Aarhus County Council (1994). Norsminde Fjord 1992. Report from the Aarhus County Council, Aarhus (in Danish)

Ertebjerg, G., Sandbeck, P., Lundøer, S., Jacobsen, F., Lykkegård, B., Jensen, J. N., Jensen, O. L. (1991). Marine områder - Fjorde, kyster og åbent hav. Vandmiljoplanens overvågningsprogram 1990. National Environmental Research Institute, Technical Report No. 40. Ministry of the Environment, Copenhagen (in Danish)

Binnerup, S. J., Jensen, K., Revsbech, N. P., Jensen, M. H., Jørgensen, J. (1992). Denitrification, dissimilatory reduction of nitrate to ammonium and nitrification in a bioturbated estuarine sediment as measured with ${ }^{15} \mathrm{~N}$ and microsensor techniques. Appl. environ. Microbiol. 58: 303-313

Borum, J. (1995). Shallow coastal areas land/sea boundaries. In: Barker, B. B., Richardson, K. (eds.) Eutrophication in a coastal marine environment. American Geophysical Union (in press)

Boynton, W. R., Kemp, W. M., Keefe, C. W. (1982). A comparative analysis of nutrients and other factors influencing estuarine phytoplankton production. In: Kennedy, V. S. (ed.) Estuarine comparisons. Academic Press, New York, p. $69-90$

Cahoon, L. B., Beretich, G. R., Thomas, C. J, McDonald, A. M. (1993). Benthic microalgal production at Stellwagen Bank, Massachusetts Bay, USA. Mar. Ecol. Prog. Ser. 102: 179-185

Christensen, P. B., Nielsen, L. P., Sørensen, J., Revsbech, N. P. (1990). Denitrification in nitrate-rich streams: diurnal and seasonal variation related to benthic oxygen metabolism. Limnol. Oceanogr. 35: 640-651

Danish Hydraulic Institute (1993). MIKE 21 AD + HD, Release 1.4, Users guide and reference manual. Danish Hydraulic Institute, Copenhagen

Ekebjærg: L., Justersen; P. (1991). An explicit scheme for advection-diffusion modelling in two dimensions. Appl. Mech. Eng. 88: 287-297

Greenberg, A. (1992). Standard methods for examination of water and wastewater, 18th edn. American Public Health Association, Washington, DC

Hovmand, M. F., Grundval, L., Runge, E. H., Kemp, K., Aistrup, W. (1993). Atmosfærisk deposition af kvælstof og fosfor. Vandmiljoplanens Overvågningsprogram 1992. National Environmental Research Institute, Technical Report No. 91. Ministry of the Environment, Copenhagen (in Danish)

Jorgensen, K. S., Sørensen, J. (1988). Two annual maxima of nitrate reduction and denitrification in estuarine sediment (Norsminde Fjord, Denmark). Mar. Ecol. Prog. Ser. 48: $147-154$

Kamp-Nielsen, L. (1992). Benthic-pelagic coupling of nutrient metabolism along an estuarine eutrophication gradient. Hydrobiologia 235/236: 457-470

Kristensen, E., Jensen, M. H., Aller, R. C. (1991). Direct measurements of dissolved inorganic nitrogen exchange and denitrification in individual polychaete (Nereis virens) burrows. J. mar. Res. 49: 355-377

Larsen, T., Andersen, F., Nielsen, K. (1992). Mariager Fjords næringssaltbalance. Vand Miljø 9: 46-49 (in Danish)

Nielsen, L. P. (1992). Denitrification in sediment determined from nitrogen isotope pairing. FEMS Microbiol Ecol. 86: $357-362$

Nielsen, L. P., Christensen, P. B. C., Rysgaard, S. (1994). Denitrifikation i fjorde og kystnære farvande. Havforskning fra Miljestyrelsen No. 50. Danish Environmental Protection Agency, Copenhagen (in Danish)

Nielsen, L. P., Sloth, N. P. (1994). Denitrification, nitrification and nitrogen assimilation in photosynthetic microbial mats. In: Stal, L. J., Caumette. P. (eds.) Microbial mats. Structure, development and environmental significance. NATO ASI Series, Berlin, p. 319-324

Nielsen, K., Sømod, B., Hansen, D. F. (1993). Eutrophication of Randers Fjord estuary, Denmark - deteriorations and improvements (1900-1991). Eur. Water Pollut. Control 3: $44-51$

North Sea Task Force (1993). North Sea Subregion 8, Assessment Report, 1993. State Pollution Control Authority, Oslo

Monbet, Y. (1992). Control of phytoplankton biomass in estuaries: a comparative analysis of microtidal and macrotidal estuaries. Estuaries 15: 563-571

Pelegri, S. P., Nielsen, L. P., Blackburn, T. H. (1994). Denitrifi- 
cation in estuarine sediment stimulated by the irrigation activity of the amphipod Corophium volutator. Mar. Ecol. Prog. Ser. 105: 285-290

Riisgård, H. U. (1991). Suspension feeding in the polychaete Nereis diversicolor. Mar. Ecol. Prog. Ser. 70: 29-37

Risgaard-Petersen, N., Rysgaard, S., Nielsen, L. P., Revsbech N. P. (1994). Diurnal variation of denitrification in sediments colonized by benthic microphytes. Limnol Oceanogr. 39: 573-579

Rysgaard, S., Christensen, P. B., Nielsen, L. P. (1995). Seasonal variation in nitrification and denitrification in estuarine sediment colonized by benthic microalgae and bioturbating infauna. Mar. Ecol. Prog. Ser. (in press)

Ryther, J. H., Dunstan, W. H. (1971). Nitrogen, phosphorus and eutrophication in the coastal marine environment Science 171: 1008-1013

Sand-Jensen, K., Borum, J. (1991). Interactions among phytoplankton, periphyton and macrophytes in temperate freshwaters and estuaries. Aquat. Bot. 41: 137-175

Sand-Jensen, K., Nielsen, S. L., Borum, J., Geertz-Hansen, O. (1994). Fytoplankton- og makrofytudviklingen i danske kystområder. Havforskning fra Miljøstyrelsen No. 30. Danish Environmental Protection Agency, Copenhagen (in Danish)

Seitzinger, S. P. (1988). Denitrification in freshwater and in coastal marine ecosystems: ecological and geochemical significance. Limnol. Oceanogr. 33: 702-724

This article was presented by T. Kiorboe (Senior Editorial Advisor), Charlottenlund, Denmark
Seitzinger, S. P. (1990). Denitrification in aquatic sediments. In: Revsbech, N. P., Sørensen, J. (eds.) Denitrification in soil and sediment. Plenum Press, New York, p. 301-322

Sfriso, A., Pavoni, B., Marcomini, A., Orio, A. (1992). Macroalgae, nutrient cycles and pollutants in the lagoon of Venice. Estuaries 15: 517-528

Valilea, I., Foreman, K., Lamontagne, M., Hersh, D., Costa, J., Peckol, P., De Meo Anderson, B., D'Avanzo, C., Babione, M., Sham, C., Brawlew, J., Lajtha, K. (1992). Couplings of watersheds and coastal waters: sources and consequences of nutrient enrichment in Waquit Bay, Massachusetts. Estuaries 15: 443-457

Walling, D. E., Webb, B. W. (1981). The reliability of suspended sediment load data. Int. Ass. Hydrol. Sci. Publ. No. 133, p. 177-194

Warren, I. R., Bach, H. K. (1992). MIKE 21: a modelling system for estuaries, coastal waters and sea. Environ. Software 7: $229-240$

Water Consult (1993). Norsminde Fjord. Undersøgelse af vandskifte- og næringssaltforhold. Report to Aarhus County Council. Water Consult, Glumsø (in Danish)

Wulff, F., Stigebrandt, A., Rahm, L. (1990). Nutrient dynamics of the Baltic Sea. Ambio 19: 126-133

Yoon, W. B., Brenner, R. (1992). Denitrification and oxygen consumption in sediments of two south Texas estuaries. Mar. Ecol. Prog. Ser. 90: 157-167

Manuscript first received: August 2, 1994

Revised version accepted: December 1, 1994 